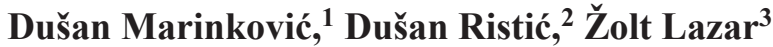 \\ University of Novi Sad, Faculty of Philosophy, Dr Zorana Đinđića 2, RS-21000 Novi Sad \\ ${ }^{1}$ dusan.marinkovic@ff.uns.ac.rs, ${ }^{2}$ risticd@ff.uns.ac.rs, ${ }^{3}$ zolt.lazar@ff.uns.ac.rs
}

\title{
Genealogy of the Other and Practices of Spatialization
}

\begin{abstract}
This paper is founded on the initial presupposition of the implicit presence of the static and non-dialectic space of physical geography in anthropology and sociology in the 19th century. Unlike anthropology which discovered the exotic Others as a dramaturgy in space lacking history the sociology of the Other and its social significance are revealed on the basis of a daily present closeness, 'at home'. We claim that the discovered Others were first spatialized in an unhistorical and non-dialectical manner, like space itself. The subsequent theoretical and epistemological spatial regionality led to the regionalization of Otherness. We conclude that discourses of many regionally constructed Othernesses appeared in anthropology, sociology and social sciences only after the spatial turn and the understanding of the process of spatialization as social technology of power, i.e. production of space.
\end{abstract}

\section{Keywords}

geo-epistemology, Other, power/space, regionalization, spatialization

\section{Introduction: \\ Implicit presence of space and the Other}

The establishment of social sciences in the 19th century as an autonomous sphere of knowledge in comparison with old metaphysics, and the previous domination of the epistemological and methodological legitimacy of natural sciences did not leave much space for space. The politics of the formation of identity of social sciences happened, on the one hand, under the domination of time - historical time, history - and on the other, under the domination of the Cartesian-Kant binary division of space into its extending morphology (rex extensa) and into transcendental aesthetics of a priori categories in which space appears as a necessary (internal) condition of the manifestation of (external) empirical world and experience.

However, even then the young social science did not find history to be a diachronic narration - a story. It found it reshaped in various forms of historicism - as a necessity of the historical movement towards final forms, as temporal dynamics of modernization. It found man to be more a product of historical determinations than history as a human plan (Collingwood 1994: 65).

While social science fought for the authenticity of its identity through the "politics" of autonomy of the social which history provided with the temporal dimension of the changeability of forms, not much space remained in geography for the authenticity of space. By creating new boundaries and fields in the battle for disciplinary identities, geography, the science of boundaries and spaces, found itself on the verge of new fields of knowledge: sociology, 
anthropology, political economy, psychology and linguistics. Dialectics, changes, life, work, language - these conjunctures were pulled into these new fields of historicized social sciences leaving to geography space as an object of measurement, proportions, distance of immobile points. It was "squeezed out of the competitive battleground of theory construction" and its "analysis and explanation was reduced to little more than describing the stage-setting where the real social actors were deeply involved in making history" (Soja 1989: 31). It was a geography of rigid cartography and morphology defined in advance - the old, slow geography (Paasi 2001:18).

By not dealing with space as its immediate subject but instead by "borrowing" this subject from geography, social sciences actually borrowed a concept of space which, for a long time, was only a natural, geomorphological, climatic or ecological scenography; a background before which a historicized dramaturgy of society, man and culture took place.

In this very space, borrowed from old geography, social sciences found the Others. Anthropological, spatialized Other was not the one that arrived at the universality of rationality, of regularity, of modernity as a historical necessity of moving towards freedom. This Other, that was discovered in space without a rich and dynamic, alive and dialectic history, was just like our old representation of space: frozen and static. If we "spatialize" Said's view of the Other, then "orientalism" is a much wider concept. It is part of a geo-epistemological apparatus of analysis (Marinković and Ristić 2016) or Foucault's dispositive with which the implicit presence of the non-dialectic space in anthropology and sociology of the 19th and beginning of the 20th century reveals the exotic distant Other [the most other (Hannerz 1986: 363; Gupta and Ferguson 1992: 6)] as a dramaturgy in space; but with a lack of history. Actually, the European study of history was a study of itself. To look into space meant to admit to itself all its colonial pretensions - the colonization of space of the exotic Other with European history; to admit that we colonized Others, that we saw them in space - but without history or society, even "omitted" from evolution (Lévi-Strauss 2013: 19). It was space understood as landscape (Cresswell 2004: 10), as a point of view, a view of the Other. It was space drenched with our, not with the history of the Other.

When, many decades later, social scientists returned to spaces through historical reflection, they found the effects of the performance of knowledge/ power: spaces became inseparable from the concepts of power, domination, classification, distribution, strategy, exclusion (Sibley 1998), deterritorialization (Balibar 2009; Deleuze and Guattari 1987; Williams 2008), heterotopy (Foucault 1986), panopticon (Foucault 1995; Elden 2003; Dobson and Fisher 2007), simulacrum (Baudrillard 1995), the virtual (Shields 2005), hyperspace (Jameson 1997: 38), marginality (Hadziavdic 2012), rooting out, displacements (Robertson et al. 1994), and finally, human practices as a key word in anthropology (Hannerz 1986: 364). That is what Foucault did in his historical analyses of new spatialized practices of discipline, surveillance, punishment, sexuality and madness. Foucault unsettled the old subject matter of geography (Foucault 1980b: 149) - space that is "static and bound", space that "freezes time and remains unshifting and dull" (Cresswell 1996: 159).

Social scientists ascribed westerners to the social forms of power, the history of development, to the forms of authority and law, while they abandoned "un- 
historicity" of the eternal and universal prohibition of incest to anthropological Others:

"See, for example, in ethnological studies from Durkheim to Lévi-Strauss, what was the problem that would always reappear, perpetually re-worked: a problem of prohibition, essentially the prohibition of incest." (Foucault 2007: 154)

Perhaps anthropology and sociology could not see these Others for a long time because of the 'borrowed' concept of space; instead, they had to develop different concepts of space - a different spatialization of the Other. The first spatially directed social research occurred in the mid-19th century with the idea on the "spatial reflection" of social groups. Spaces began to be understood as a reflection of a functional organization of society (Maier et al. 1977). But only with Durkheim and Mauss (1903) began the first impulses to crush the Cartesian-Kant space in those places in The Elementary Forms of Religious Life (Durkheim 1995: 10), where space was returned to human practices. Durkheim's break with the implicit domination of the borrowed concept of space was one of the first indications of the regionalization and heterogeneization of space in social sciences and of what would later be recognized as the social construction of space (Gupta and Ferguson 1992: 11).

This surely does not mean that we should neglect geography or reject it as an old paradigm of spatialization, because geography itself transformed into understanding a new comprehension of space (Crang \& Thrift 2003; Elden 2001; Gupta and Ferguson, 1997; Harvey 1992; 2005; Lefebvre 2007; Pickles 2009; Soja 1980; Soja 1989). Like Michel Foucault (1986) demonstrated, without any pretension of systematization in the study of geography, in this field of geo-epistemology we recognize knowledge, power (power) knowledge), discursive creation, view, episteme... a system of an organized scatteredness (Foucault 1980a; Gür 2002). Although the geography of scatteredness is a concept from physical geography, where it signifies the lack of connection between spatial entities, we use it in a metaphorical sense as a concept of "political geography", that is, as "a space of scatteredness; an open field of relations which, undoubtedly, can be described infinitely" (Foucault 1994a: 676). As opposed to the "old geography" of once firmly defined political constructs (territories, borders, states), scatteredness is a hint of "irreversible disorder" (Foucault 1994b: 450), which refers simultaneously to old political relations as well as to identities and traditional subjectivities (Marinković and Ristić 2015a).

This is geo-epistemology which wants to understand "its" constitutive concepts in a different way - the concepts where history, anthropology, sociology, economy, geopolitics and archaeology encounter each other. If we add the concepts of the Other and Otherness to the problem of space, the geography of large and clear areas turns into a micro-geography of small differences and small "regions" with unclear boundaries, in geo-epistemology. As Neumann says, "in the case of regions, it is actually possible to support this insistence on the existence of the nexus knowledge-power" (Neumann 1999: 115), which means that in the case of regions, it is not only about geopolitical dimensions included in the politics of identity, but also about geo-epistemological and geo-axiological knowledge, values and power. Geo-epistemological analysis is the analysis of knowledge and discourses which are formed through spaces and the analysis of space formed through knowledge/power/discourses (Marinković, Šljukić and Ristić 2015). In other words, these are the spaces where speech, technologies and power/knowledge are placed. 


\section{Multiple sources of the renewal of the spatialization of the Other: From Vico to Foucault}

The first founders of humanity applied themselves to sensory topics... And first it began to hew out topics...

(Vico 1948: 149)

Spatialization of the Other occurred sporadically in various periods of the development of sociology and anthropology, as well as in different theoretical traditions in Europe ${ }^{1}$ and the United States of America. This was especially valid for 19th century anthropology, whose development was significantly spatialized (Marcus and Fischer 1986: 97). It seems, however, that there was a certain early parallelism between anthropology and sociology in the discovery of the distant and close Other. Anthropology as a par excellence discipline of differences and of the Other was faced with this problem "since long before that word was spelled with a capital O" (Sax 1998: 292). But almost at the same time sociology discovered the Other and its social significance, but on the level of the daily present looseness ${ }^{2}$ - at home, as Marcus and Fischer (1986) indicated. In the cases of both the distant and close Other, space was more or less implicitly present. In both cases these spatially close and spatially distant Others were inherited topics (Augé 1989).

As early as with Giambattista Vico, in his Scienza Nuova - a book that was discovered quite late - we encounter questions of the spatialized Other as well as the problem of the borders of the Other. By ascribing to aristocratic societies the establishment and maintenance of the borders/boundaries towards the Others as one of their most sublime qualities, Vico noticed that "on these boundaries were to be fixed the frontiers first of families, then of clans or houses, later of peoples, and finally of nations" (Vico 1948: 327).

What is even more significant is Vico's realization that the new science needed "to cleanse the other eye of poetic history, namely poetic geography" (Vico 1948: 254). We should add to this that Vico's spatialization through borders is not an authentic discovery, it can be found as early as in Plato's Laws, in that place where a neighbor, a townsman and a stranger encounter each other in the region of borders. This idea is surely older than Plato as well. It is a heritage of ancient Greek mythological geography (of borders) which needed Zeus Herkeious - "the protector of border lines" (Arendt 1998: $30)$. An even more significant thing was that his new performative epistemology verum ipsum factum did not refer only to history, but also to geography, because the presence of man is an idea on "the geographical agent" (Mills 1982: 8). In that sense, Vico's geography was even then a break from the Cartesian space - anti-cartesianism (Collingwood 1994). It was a geography of knowledge, an epistemological geography, a philosophy of space and place (Kunze 1983).

Four years before Vico's Scienza Nuova was published, Montesquieu's Persian Letters were a discovery of easterners as ancient European Others via the question if it was even possible not to be a European and what it was like to be the Other - different from what is acceptable as civilized. Growing distant from a familiar and close geography, crossing the borders of an advanced kingdom, Montesquieu says in Usbek, simultaneously means crossing the borders of our knowledge: 
"We were born in a prosperous realm, but did not believe its boundaries should be the boundaries of our knowledge, and that the light of the Orient need be the only light to illuminate our path." (Montesquieu 2008: 4)

Like with Vico, this is more a geo-epistemological than a physical-geographical insight. Through these early, imaginary anthropological travels Montesquieu offered to future anthropology and sociology a model of a comparative approach to the Other with a warning that the Other is no substantial category, but a matter of borders that are drawn, established and defended between $u s$ and the others. Besides the Other, Montesquieu also revealed to future anthropology and sociology new meanings of borders, i.e. an aspiration to leave our present boundaries and to use borders to avoid one another (Montesquieu 2008: 156). Montesquieu actually did not manage to escape his own European view (Lorenso 2011: 45).

We cannot omit here the hidden geography of the Other in Michel de Montaigne's work, in which we can recognize the anticipation of Vico's idea on the epistemology of space and elements of a geo-epistemology. His most significant contemplations on the connection of geography and thought are found precisely in that part where Europe meets an exotic, but wild, Other; On Cannibals. It is precisely here that Montaigne faces us with the epistemology of the local; a regional which has a problem the moment it steps out into a different, distant geography of the spaces of Others:

"Indeed we seem to have no other criterion of truth and reason than the type and kind of opinions and customs current in the land where we live." (Montaigne 1993: 108-109)

Besides this, in what is probably his most significant geo-epistemological insight, Montaigne criticizes even what we could call an epistemological topography, an anthropo-epistemological cartography (Montaigne 1993: 108).

Just like with Vico, here also exists an anticipation of a deviation from Cartesian geography (surely, several decades before Descartes himself):

"I do not believe, from what I have been told about this people, that there is anything barbarous or savage about them, except that we all call barbarous anything that is contrary to our own habits." (Montaigne 1993: 108)

In a certain sense, this anthropo-epistemological cartography of Montaigne's anticipated what would be articulated only in Said's imaginative geography of Orientalism (1979) as a dualistic epistemology of the occidental and oriental (Sax 1998: 292). However, Montaigne's anthropological cartography and topography reach right to the previously mentioned idea of Foucault's; that there is also one much deeper dualism between us and them. This is a dualism that produces a new map - topology and cartography of power (and authority) which hides a desire to socially localize and regionalize the West. On the other hand, culture as a hidden term has always been "the essential

1

"The theme of 'the Other' - and specially what constitutes the Otherness of 'the Other' - has been at the very heart of the work of every major twentieth-century Continental philosopher." (Bernstein, 1991: 68) According to Iver Neumann (1999), the theme of "the Other" has been central to at least one social discipline - social anthropology, but it has also been of interest in fields such as philosophy, psychology, sociology and literary theory.
2

Contemporary research on the Other and Otherness "at home" or at the level of daily present closeness is still not an exclusive field of research of sociology. For instance, anthropologist Jonathan Friedman writes that Otherness "begins at home, with our primary Others" (1991: 99). 
tool for making Other" (Abu-Lughod 1991: 143) - as them. If we remember Foucault's (2007: 154) quotation that ethnology since Durkheim and LeviStrauss limited the power of prohibition of incest, i.e. that it was essentially an ethnology of rules, an ethnology of prohibition, then this is the hidden yet always present deep dichotomy of society (us) and culture (them).

Although Foucault's intention was of a different nature, to show "how is it that our society, Western society in general, has conceived power in such a restricted, such a poor and such a negative way?" (2007: 154). In it we can recognize Montaigne's announcement of the geo-epistemology of the spatialized Other.

\section{Presence of the stranger - approximation of the Other}

Your Christ is a Jew. Your car is Japanese. Your pizza is Italian. Your democracy - Greek. Your coffee-Brazilian. Your holiday - Turkish. Your numbers - Arabic. Your letters - Latin. Only your neighbor is a foreigner.

(Bauman 2004: 27)

Without these early pre-sociological theoretical experiences in the analysis of the Other it would be difficult to imagine the "originality" of Simmel's (1950) and later Schütz's (1944) Stranger, as well as the recurring sociological discoveries of the Other, via European influences, in the tradition of American sociology, primarily via Thomas' The Unadjusted Girl (1967), the Polish (immigrant) Other by Florian Znaniecki (Thomas and Znaniecki 1984), Wirth's ghettoized Other (1958) and Park's marginalized Other, expressed in various degrees of distance (Park 1928). Surely, there is also Mead's generalized other (2003) as our social, socialized alter-ego. There is no doubt that the most significant frame of discovering the Other in sociology in the United States was the Chicago School in the period between the world wars, but there is also no doubt that European influences, first by Georg Simmel and then by Alfred Schütz, provided the most direct stimulation for the development of this understanding of the Other.

After this period, Other was discovered in sociology several more times, each time in a different way. Certainly the most fruitful manner of this re-discovery in sociology, which synthesized previous viewpoints, was Goffman's stigmatized Other (1963) as well as captured Other, divided from the rest by impenetrable borders of total institutions (Goffman 1961). This very captured spatialized other by Goffman is one of rare sociological references which occur in the construction of Foucault's Others as those who are the products of new kinds of knowledge and discursive practices: psychiatry, law, medicine, pedagogy, psychology (Foucault 2003; 2006). When the discoveries of these Goffmanian and Foucauldian Others started to emerge, almost simultaneously, in the 1960 s, they found themselves in the middle of a great ruling paradigm of structural functionalism which still had no sensitivity or space for small intensities (Weber 1978) for the differences between "regional" types as well as those who were 'small' either in a static and/or empirical sense and, therefore, had 'small' theoretical significance. To be statistically irrelevant, socially absent, culturally marginalized and politically excluded still does not mean to be insignificant for research. On the contrary, as Cresswell writes,

“... marginal, grotesque, extraordinary elements and events in society are interesting in themselves, but they are more interesting when we examine the role they play in defining the "normal', the classical, the dominant. The center could not exist without the margin." (Cresswell 1996: 149) 
Peter Stallybrass and Allon White (1986) also argue that "what is socially peripheral is often symbolically central".

Simmel's sociological and Schütz's social psychological stranger (Simmel 1950; Schütz 1944) are the most immediate and most original frameworks for analysing the regional Other as the one that is present and close, yet simultaneously recognized as different. In that sense the stranger is the regional Other produced in the drawing of porous and fluid borders that cut through the same time and space. At the same time, space is not a minor inevitability in which social relations take place, i.e. an inevitable background to eventfulness:

"Spatial relations are only the condition, on the one hand, and the symbol, on the other, of human relations." (Simmel 1950: 402)

Every stranger, like the Other, is thus "fixed within a particular spatial group, or within a group whose boundaries are similar to spatial boundaries" (Simmel 1950: 402). The regional production of new spaces occurs as the production of new borders (or borders analogue to spatial ones) in which the Other appears not "as the wanderer who comes today and goes tomorrow, but rather as the person who comes today and stays tomorrow" (Simmel 1950: 402) - as the one who stays in the newly produced (or rather defined) spaces. And his "position in this group is determined, essentially, by the fact that he has not belonged to it from the beginning, that he imports qualities into it, which do not and cannot stem from the group itself' (Simmel 1950: 402).

This Simmelian interpretation of the Other as a stranger solves one, at first glance, paradoxical situation. Namely, easily seen great differences (social, cultural, political) do not necessarily produce conflicts of great intensity. Radically different Others most often remain distant Others, beyond the space and borders defined as ours and theirs. On the other hand, the very closeness of the stranger and closeness of the defined other is a source of constant potential tension. This can refer precisely to the regional other, who is not just a stranger who "came" and stayed, but also the one who is produced in our immediate vicinity, within the once commonly defined space and its boundaries (Simmel 1950: 406).

There are surely those who do not stay, who cannot be held by any borders, asylums, states or nations. Today there are probably many more of them than in the time when Simmel defined them as the ones who come and stay. ${ }^{3}$ These are strangers in constant passing, wandering, who will not be stopped by the identity of any locality or regionality of space - the ones whose identities are floating, wandering, fluid, liquid (Bauman 2000; 2004) - unanchored. These are new nomads, (we) refugees (Arendt 1994), migrant workers, "those who cross borders more or less permanently - immigrants, refugees, exiles, and expatriates. In their case, the disjuncture of place and culture is especially clear" (Gupta and Ferguson 1992: 7). It is difficult in fluid modernity to redraw the cartography of old borders - between us and them; for it is now us who "seek and construct and keep together the communal references of our identities while on the move" (Bauman 2004: 26).

Simmel's discovery of the sociological significance of the stranger has long been extended to other sociological fields and has thus acquired the status of a generally known fact. Therefore, these general sociological findings can

On the problems of identification of Others in anthropology see Cohen (1989). 
be applied without methodological and theoretical fear to the regional Other. This applicability can primarily find its place in those seemingly confusing social situations in which one "does not expect" the close, regional Other to become a stranger. Furthermore, what is little expected is for the relation to the close Other, as a relation of differences of small intensities, to produce conflicts greater than the ones with distant Others. This necessity for a periodical production of significant, great Others (in Europe) and new relations with regional Others will be discussed in the next section.

\section{Regionalization of the Other}

It can be presumed that one of the important reasons for multiple meanings of spaces we returned to, i.e. for the theoretical and epistemological spatial regionality, is the fact that there were quite different sources of the renewal of interest in spaces and spatialization: from the rediscovery of space by Vico and Montesquieu, to Lefebvre's, and later, David Harvey's specific neomarxism as well as Foucault's view (which must be understood as authentic despite various influences that shaped it). The multiplicity and heterogeneity of space signified the fact that it became a variable of social interaction. In the same manner, the spatial turn (Warf and Arias 2009) implied that the frequently used spatial metaphors (Keith and Pile 1993: 1, 35) - useful metaphors (Smith and Katz 1993: 68) - in social sciences transformed into analytical and epistemological instruments.

Regionalized and heterogeneized spaces no longer have the features of old descriptive regional geography (Cresswell 2004: 16). They can also exist as deterritoralizing entities ${ }^{4}$ or as Straussian floating signifiers (Lévi-Strauss 1963 ) with shapes that are never clear, but with visible effects of their action. We can say that despite great ruling patterns in which the distant, "the most Other of Others" (Hannerz 1986: 363) appear, there are less distant, regional Others - multitudes of regionally constructed Othernesses, not only in comparison with those great ruling patterns (according to which the Other appears as an opposite, as a stranger), but precisely because of the great patterns that produce them; and yet do not have to necessarily determine their spaces and place - "the Other" need not be exotic:

"The anthropologist reports not on the remote exotic but on the nearly familiar." (Kuklick 1997: 64$)^{5}$

Discourses on regional Other and Otherness could occur only when spatial relations in research in social sciences began to be understood not only as formal geometries, but as substantive geographies (Philo 2003: 228); and only when knowledge itself became regionalized (Foucault 1980a: 69).

Only when the control and division of space and time became "a fundamental means by which knowledge and power came to be exercised increasingly over all spheres of society" (Zieleniec 2007: 130). And finally, when it was discovered that nothing is external to power, because it is implicated in all that we are and all that we inhabit (Allen 2003: 65-66).

This was made possible primarily because of the Lefebvre-Foucault-Harvey trihedral, who understood space as a product of human practices, practices and technologies of power:

"If we have learned anything, it is that spaces and places essentially are conflicted: they are sites of struggle" (Gabbert and Jordan-Smith 2007: 217. Paul Veyne (1997) very simply determined the concept of practice in the context of attempts to explain Foucault's revolutionizing of history: 
"Practice is not some mysterious agency, some substratum of history, some hidden engine; it is what people do (the word says just what it means)." (Veyne 1997: 153)

Although Lefebvre, Foucault and Harvey belong to different theoretical traditions, their interest in space connects the crucial concept of human practice - a polyvalent concept which, in any case, connects the theoretical heterogeneity of neomarxism with very different theories and discourses. On the other hand, we can connect these three important authors with an idea that practices of spatial production can be understood as social practices which implicitly contain technologies of power (Marinković and Ristić 2015b).

Michel Foucault used special metaphors to indicate that 'the picturesque speech of liberated space' represents an important analytical means for exploring power. According to Foucault, space has become a great obsession of our time (Foucault 1980b). We are in the epoch of the simultaneous, parallel, close and distant to the epoch, neighbouring and scattered (Foucault 1986). However, what is a key connection that Foucault managed to establish is a connection of discursive practices, spaces and power (Foucault 1980b: 149).

In other words, "the spatialising description of discursive realities" for Foucault "gives on to the analysis of related effects of power" (Foucault 1980a: 70-71). The control and division of space thus became a fundamental means by which knowledge and power came to be exercised over all spheres of society. The diagram of power whose points of intersection and effects can be researched in regionalized spaces of the Others - in their social practices - (Deleuze 2006: 34). That diagram of space/power of regionalized Otherness (Marinković and Ristic 2015a) can be understood as coextensive with the fields of regional sites - a diffuse network of practices of spatialization. A crucial element in this view of space/power is that the interleaving of relationships does not happen in a matrix "from above" or "from behind", but simultaneously - through the relationships produced within the various social practices.

We are, therefore, no longer talking only about spatial imagery of Otherness among social actors, nor of spatial metaphors in analysis, but of elements of a geo-epistemological analysis of space/power, which recognize the importance of mapping the flatten field of objective relations among variabilities: among centre and periphery, among forces that constitute space/power relations, immanent in social practices. In this sense, different regional arrangements of space/power can be understood as "integral to the ways in which particular forms of conduct are secured" or seen "as having much to do with fixing people down as with facilitating their distribution and circulation through an intricate web of relationships" (Allen 2003: 70). Regions of social Otherness (now it is irrelevant if they are close or distant, here, at our borders or far from us) as social arrangements of practices of space/power can no longer be understood in categories of static forms of spatialization. As distant, separated, unknown, "frozen" in space as res extensa, regional Others can be here today and tomorrow in a completely different place.

In that sense, the regional Other is a matter of setting new kinds of borders which produce social Otherness. Social practices of producing space by establishing borders is preceded by a classification. Actually, there are no classifications without borders (a classification is setting the borders), nor are there

In a vague, metaphorical way, de-territorialization refers to the dissolution of borders, boundaries and the anthropological "field" (Kokot 2006).
5

According to Gupta and Ferguson (1997: 4) cultures "are no longer fixed in places". 
borders without a classification (borders are the product of classification). The regional Other also appears as another important dimension of our representations of classified entities that are expressed in a hierarchical principle of sociality.

\section{Conclusion}

We can quite rightly ask if the spatialization of the regional Other belongs to the domain of the significant Others and if we have methodological instruments developed enough to recognize those floating, fluid differences as important. This question should be primarily understood as "a research question, and not a question of conjecture"; a question "to decide which diacritica mark a particular self/other nexus, between nations as well as between other human collectives" (Neumann 1999: 5).

We should say that, at least in the European context of intensive regionalization, the production of the Other is not a new topic. It has a long history. This is the history of Europe itself, its duration and its identity - the history of its self-recognizability:

"A variety of Others have been and are instrumental in the process of forging European identity.” (Neumann 1999: 39)

At the same time this matrix of European long production of the Other is a reality which we can see with eyes wide open. It shapes us like it always has. It is the part of European "identity", although Europeans "no longer know themselves; they ignore their mixed ancestries and seek a proper role" (Foucault 1984: 92). Its currentness, just like its history, is invitation enough for researching the regional Other or regional Others because without that insight it would not be possible to understand and explain the European multifacetedness; its ethnical, cultural, linguistic, social, political, economic, religious heterogeneity; and, certainly, its ancient and never fully completed search for its own borders - geographical as well as cultural, political and social - which it will determine in comparison with itself and through its great and significant Others with whom it has undertaken an uninterrupted millennial dialogue (Marinković and Ristić, 2015a). The scope of the problematization of these topics has not omitted the necessity of geography and new forms of spatialization, redefinition of former firm borders, as well as the consideration of new meanings of the very concepts of practice, space and border.

In a similar manner, the currentness of the geopolitical discourse on regions and regionalization necessarily imposes new forms of distribution and redistribution of power, new forms of political participation, new forms of political divisions and influences which have their spatial forms, zones, classifications, areas, territories, places - and maybe even a new form of analysis: a geo-epistemology of space/power.

\section{References}

Abu-Lughod, L. (1991): "Writing Against Culture", in: Fox, R. G. (ed.): Recapturing Anthropology: Working in the Present. Santa Fe, New Mexico: School of American Research Press, pp. 137-162.

Allen, J. (2003): Lost Geographies of Power. Oxford: Blackwell Publishing.

Arendt, H. (1994): “We Refugees", in: Robinson, M. (ed.): Altogether Elsewhere: Writers on Exile. Boston and London: Faber and Faber, pp. 110-119. 
Arendt, H. (1998): The Human Condition. Chicago and London: The University of Chicago Press.

Augé, M. (1989): “L'autre proche”, in: Segalen, M. (ed.): L'autre et le semblable. Paris: Presses du CNRS, pp. 19-33.

Balibar, E. (2009): "Europe as Borderland", Environment and Planing D: Society and Space 27 (2/2009), pp. 190-215. doi: https://doi.org/10.1068/d13008.

Baudrillard, J. (1995): Simulacra and Simulation. Translated by Sheila Faria Glaser. Michigan: University of Michigan Press.

Bauman, Z. (2000): Liquid Modernity. Cambridge: Polity Press.

Bauman, Z. (2004): Identity: Conversations with Benedetto Vecchi. Cambridge: Polity Press.

Bernstein, R. J. (1991): The New Constellation: The Ethical-Political Horizons of Modernity/Postmodernity. Cambridge: Polity.

Collingwood, R. G. (1994): The idea of history. Revised edition with Lectures 1926/1928. Oxford and New York: Oxford University Press.

Cohen, A. P. (1989): “La tradition britannique et la question de l'autre", in: Segalen, M. (ed.): L'autre et le semblable. Paris: Presses du CNRS, pp. 35-51.

Crang, M.; Thrift, N. (eds. 2003): Thinking Space. London - New York: Routledge.

Cresswell, T. (1996): In Place/Out of Place: Geography, Ideology, and Transgression. Minneapolis: University of Minnesota Press.

Cresswell, T. (2004): Place - A Short Introduction. Malden, Oxford: Blackwell.

Deleuze, G.; Guattari, F. (1987): A Thousand Plateaus: Capitalism and Schizophrenia. Translated by Brian Massumi. Minneapolis and London: University of Minnesota Press.

Deleuze, G. (2006): Foucault. Translated by Seán Hand. Minneapolis: University of Minnesota Press.

Dobson, J. E.; Fisher, P. F. (2007): "The Panopticon's Changing Geography", Geographical Review 97 (3/2007), pp. 307-323. doi: https://doi.org/10.1111/j.1931-0846.2007. tb00508.x.

Durkheim, É.; Mauss, M. (1903): "De quelques formes primitives de classification", $A n$ née sociologique 6 (1903), pp. 1-72. Available at: http://classiques.uqac.ca/classiques/ mauss marcel/essais de socio/T7 formes classification/formes classification.pdf (accessed on February 27, 2017).

Durkheim, É. (1995): The Elementary Forms of Religious Life. New York: The Free Press.

Elden, S. (2001): Mapping the Present: Heidegger, Foucault and the Project of a Spatial History. London - New York: Continuum.

Elden, S. (2003): "Plague, Panopticon, Police", Surveillance \& Society 1 (3/2003), pp. 240-253.

Foucault, M. (1980a): "Questions on Geography”, in: Power/Knowledge Selected Interviews and Other Writings 1972-1977 Michel Foucault. New York: Pantheon Books, pp. $63-77$.

Foucault, M. (1980b): "The Eye of Power", in: Power/Knowledge Selected Interviews and Other Writings 1972-1977 Michel Foucault. New York: Pantheon Books, pp. 146-166.

Foucault, M. (1984): "Nietzsche, Genealogy, History”, in: Rabinow, P. (ed.): The Foucault Reader. New York: Pantheon Books, pp. 76-100.

Foucault, M. (1986): “Of Other Spaces”, translated by Jay Miskowiec, Diacritics 16 (1/1896), pp. 22-27. doi: https://doi.org/10.2307/464648.

Foucault, M. (1994a): “Réponse à une question", in: Dits et écrits 2, 1954-1969. Paris: Gallimard, pp. 673-695. 
Foucault, M. (1994b): "Structuralisme et poststructuralisme", in: Dits et écrits 4, 19801988. Paris: Gallimard, pp. 431-453.

Foucault, M. (1995): Discipline and Punish: The Birth of the Prison. Translated by Alan Sheridan. New York: Vintage Books.

Foucault, M. (2003): Abnormal: Lectures at the College de France, 1974-1975. Translated by Graham Burchell. London - New York: Verso.

Foucault, M. (2006): Psychiatric Power: Lectures at the College De France, 1973-74. Translated by Graham Burchell. New York: Palgrave, Macmillan.

Foucault, M. (2007): “The Mashes of Power", in: Crampton, J. W.; Elden, S. (eds.): Space, Knowledge and Power: Foucault and Geography. Translated by Gerald Moore. Burlington: Ashgate.

Friedman, J. (1991): "Further Notes on the Advents of Phallus in Blunderland", in: Nencel, L.; Pels, P. (eds.): Constructing Knowledge: Authority and Critique in Social Sciences. Inquiries in Social Construction. London: Sage, pp. 95-113.

Gabbert, L.; Jordan-Smith, P. (2007): “Introduction: Space, Place, Emergence”, Western Folklore 66 (3-4/2007), pp. 217-232. doi:

Goffman, E. (1961): Asylums. Essays on the Social Situation of Mental Patients and Other Inmates. New York: Anchor Books.

Goffman, E. (1963): Stigma: Notes on the Management of Spoiled Identity. London: Penguin.

Gupta, A.; Ferguson, J. (eds. 1997): Anthropological Locations: Boundaries and Grounds of a Field Science. Berkeley: University of California Press.

Gupta, A.; Ferguson, J. (1992): "Beyond 'Culture'. Space, Identity and the Politics of Difference”, Cultural Anthropology 7 (1/1992), pp. 6-23. doi: https://doi.org/10.1525/ can.1992.7.1.02a00020.

Gür, B. F. (2002): "Spatialisation of Power/Knowledge/Discourse: Transformation of Urban Space Through Discursive Representations in Sultanahmet, Istanbul", Space and Culture 5 (3/2002), pp. 237-252. doi: https://doi.org/10.1177/1206331202005003004.

Hadziavdic, H. (2012): “Gypsies as 'Marginal Man' in Works by Georg Simmel and Robert Park”, Rocky Mountain Review 66 (1/2012), pp. 32-44. doi: https://doi.org/10.1353/ rmr.2012.0007.

Hannerz, U. (1986): "Theory in Anthropology: Small is Beautiful? The Problem of Complex Cultures," Comparative Studies in Society and History 28 (2/1986), pp. 362-367.

Harvey, D. (1992): The Condition of Postmodernity. Cambridge, MA: Blackwell.

Harvey, D. (2005): “Space as a Key Word”, in: Spaces of Neoliberalization: Towards a Theory of Uneven Geographical Development, Hettner-Lecture 2004. Heidelberg: Franz Steiner Verlag, pp. 93-115.

Jameson, F. (1997): Postmodernism, or the Cultural Logic of Late Capitalism. Durham: Duke University Press.

Keith, M.; Pile, S. (eds. 1993). Place and the Politics of Identity. London - New York: Routledge.

Kokot, W. (2006): "Culture and Space - anthropological approaches", Etnoscripts. Available at https://www.ethnologie.uni-hamburg.de/pdfs-de/ethnoscripts-pdf/es_9_1_artikel1. pdf (accessed on February 20, 2017).

Kuklick, H. (1997): “After Ishmael: The Fieldwork Tradition and Its Future”, in: Gupta, A.; Ferguson, J. (eds.): Anthropological Locations: Boundaries and grounds of a field science. Berkeley: University of California Press, pp. 47-65.

Kunze, D. (1983): "Giambattista Vico as a Philosopher of Place: Comments on the Recent Article by Mills", Transactions of the Institute of British Geographers 8 (2/1983), pp. 237-248. doi: https://doi.org/10.2307/622114. 
Lefebvre, H. (2007): The Production of Space. Translated by Donald Nicholson. Oxford: Blackwell Publishing.

Lévi-Strauss, C. (1963): Structural Anthropology. Translated by Claire Jacobson. New York: Basic Books.

Lévi-Strauss, C. (2013): Anthropology Confronts the Problems of the Modern World. Translated by Jane Marie Todd. Cambridge (MA) - London: The Belknap Press.

Lorenso, E. [Lourenço, E.] (2011): Razočarana Evropa: prilozi za jednu evropsku mitologiju. [A Europa Desencantada Para uma Mitologia Eropeia]. Translated by Anamarija Marinović. Novi Sad: Mediterran Publishing.

Maier, J. et al. (1977): Sozialgeographie, Das Geographische Seminar. Braunschweig: Westermann.

Marinković, D.; Ristić, D. (2015a): “Regional Heterotopia of Central Europe: 'lost' identity in the process of deterritorialisation of Europe", Journal of International Relations and Development. doi: https://doi.org/10.1057/jird.2015.28 (advanced online publication, 17th July)

Marinković, D.; Ristić, D. (2015b): “Konstrukcija saglasnosti: svakodnevica i prostorne strategije neoliberalizma" ["Construction of Consensus: Everyday Life and Space Strategies of Neoliberalism], Sociologija 57 (1/2015), pp. 112-132.

Marinković, D.; Šljukić, S.; Ristić, D. (2014): “Od genealogije ka geo-epistemologiji: zaokret ka lokalnosti prostora, vremena i znanja" ["From Genealogy to Geo-Epistemology: A Turn to Locality of Space, Time and Knowledge"], Sociološki pregled 48 (3/2014), pp. 333-352.

Marinković, D.; Ristić, D. (2016): "Foucault's 'Hall of Mirrors': an investigation into geo-epistemology”, Geografiska Annaler: Series B, Human Geography 98 (2/2016), pp. 83-96. doi: https://doi.org/10.1111/geob.12092.

Marcus, G. E.; Fischer, M. M. J. (1986): Anthropology as Cultural Critique: An Experimental Moment in the Human Sciences. Chicago: University of Chicago Press.

Mead, G. H. (2003): Um, osoba i društvo sa stajališta socijalnog biheviorista [Mind Self and Society from the Standpoint of a Social Behaviorist]. Translated by Srđan Dvornik. Zagreb: Jesenski i Turk.

Mills, W. J. (1982): "Positivism Reversed: The relevance of Giambattista Vico", Transactions of the Institute of British Geographers 7 (1/1982), pp. 1-14. doi: https://doi. org/10.2307/621908.

Montaigne, M. (1993): Essays. Translated by Michael Andrew Screech. London: Penguin Books.

Montesquieu (2008): Persian Letters. Translated by Margaret Mauldon. New York: Oxford University Press.

Neumann, I. B. (1999). Uses of the Other: 'The East' in European Identity Formation. Minneapolis: University of Minnesota Press.

Paasi, A. (2001): "Europe as a Social Process and Discourse: Considerations of Place, Boundaries and Identity", European Urban and Regional Studies 8 (1/2001), pp. 7-28. doi: https://doi.org/10.1177/096977640100800102.

Park, R. E. (1928): "Human Migration and the Marginal Man", American Journal of Sociology 33 (6/1928), pp. 881-893. doi: https://doi.org/10.1086/214592.

Philo, C. (2003): "Foucault's Geography", in: Crang, M.; Thrift, N. (2003): Thinking Space. London and New York: Routledge, pp. 205-239.

Pickles, J. (2009): Phenomenology, Science and Geography: Spatiality and the Human Sciences. Cambridge: Cambridge University Press.

Robertson, G. et al. (1994): Travellers'Tales: Narratives of Home and Displacement. London and New York: Routledge. 
Said, E. W. (1979): Orientalism. New York: Vintage Books.

Sax, W. S. (1998): "The Hall of Mirrors: Orientalism, Anthropology, and the Other", American Anthropologist 100 (2/1998), pp. 292-301. doi: https://doi.org/10.1525/ aa.1998.100.2.292.

Schütz, A. (1944): "The Stranger: An Essay in Social Psychology", American Journal of Sociology 49 (6/1944), pp. 499-507. doi: https://doi.org/10.1086/219472/.

Shields, R. (2005): The Virtual. London - New York: Routledge.

Sibley, D. (1998): Geographies of Exclusion - Society and Difference in the West. London -New York: Routledge.

Simmel, G. (1950): “The Stranger”, in: Wolff, K. H. (ed.): The Sociology of Georg Simmel. Glencoe, (IL). The Free Press, pp. 402-409.

Smith, N.; Katz, C. (1993): "Grounding Metaphor: Towards a Spatialized Politics", in: Keith, M.; Pile, S. (eds.): Place and the Politics of Identity. London - New York: Routledge, pp. 66-81.

Soja, E. W. (1980): "The Socio-Spatial Dialectic", Annals of the Association of American Geographers 70 (2/1980), pp. 207-225. doi: https://doi.org/10.1111/j.1467-8306.1980. tb01308.x.

Soja, E. W. (1989): Postmodern Geographies: The Reassertion of Space in Critical Social Theory. London - New York: Verso.

Stallybrass, P.; White, A. (1986): The Politics and Poetics of Transgression. Ithaca (NY): Cornell University Press.

Thomas, W. I.; Znaniecki, F. (1984): The Polish Peasant in Europe and America. Urbana - Chicago: University of Illinois Press.

Thomas, W. I. (1967): The Unadjusted Girl: With Cases and Standpoint for Behavior Analysis. New York: Harper and Row.

Veyne, P. (1997): "Foucault Revolutionizes History", in: Davidson, A. I. (ed.): Foucault and his Interlocutors. Chicago - London: The University of Chicago Press, pp. 146-182.

Vico, G. (1948): The New Science. Translated by Thomas Goddard Bergin, Max Harold Fisch. Ithaca (NY): Cornell University Press.

Warf, B.; Arias, S. (2009): The Spatial Turn. London - New York: Routledge.

Weber, M. (1978): Economy and Society. Berkeley: University of California Press.

Williams, R. (2008): "Darkness, Deterritorialisation, and Social Control”, Space and culture 11 (2008), pp. 514-532. doi: https://doi.org/10.1177/1206331208320117.

Wirth, L. (1958): The Ghetto. Chicago: The University of Chicago Press.

Zieleniec, A. (2007): Space and Social Theory. London: Sage Publications. 
Dušan Marinković, Dušan Ristić, Žolt Lazar

\title{
Genealogija Drugog i prakse spacijalizacije
}

\begin{abstract}
Sažetak
U radu polazimo od pretpostavke implicitne prisutnosti statičnog i nedijalektičkog prostora fizičke geografije u antropologiji i sociologiji devetnaestog stoljeća. Za razliku od antropologije koja je otkrila egzotičnog i udaljenog Drugog kao dramaturgiju u prostoru s nedostatkom povijesti, sociologija Drugog njegovu društvenu značajnost otkriva na razini svakodnevno prisutne bliskosti doma. U radu tvrdimo da su otkriveni Drugi isprva bili spacijalizirani na nepovijestan i nedijalektičan način - kao i sam prostor - a da je naknadna teorijska i epistemološka prostorna regionalnost dovela do regionalizacije Drugosti. U radu zaključujemo da su se diskursi mnoštva regionalno konstruiranih Drugosti pojavili u antropologiji i društvenim znanostima tek nakon prostornog zaokreta i razumijevanja procesa spacijalizacije kao društvene tehnologije moći, odnosno proizvodnje prostora.
\end{abstract}

Ključne riječi

geoepistemologija, Drugi, moć/prostor, regionalizacija, spacijalizacija

\section{Dušan Marinković, Dušan Ristić, Žolt Lazar}

\section{Genealogie des Anderen und Spatialisierungspraktiken}

\begin{abstract}
Zusammenfassung
In der Arbeit gehen wir von der Annahme einer impliziten Präsenz des statischen und nichtdialektischen Raums der physischen Geografie in der Anthropologie und Soziologie des neunzehnten Jahrhunderts aus. Anders als die Anthropologie, die den exotischen und fernen Anderen als Dramaturgie in einem Raum mit Mangel an Geschichte entdeckte, bringt die Soziologie des Anderen dessen gesellschaftliche Bedeutsamkeit auf der Ebene der alltäglich präsenten Heimnähe ans Licht. In der Arbeit argumentieren wir, dass die entdeckten Anderen zunächst auf eine nichtgeschichtliche und nichtdialektische Art spatialisiert wurden - wie der Raum selbst-und dass die nachfolgende theoretische und epistemologische räumliche Regionalität zur Regionalisierung der Anderheit führte. In der Arbeit kommen wir zu dem Schluss, dass die Diskurse einer Vielzahl regional konstruierter Anderheiten in der Anthropologie sowie den Sozialwissenschaften in Erscheinung traten, jedoch erst nach einer räumlichen Wende und nach dem Verständnis der Spatialisierungsprozesse als gesellschaftliche Technologie der Macht bzw. der Raumproduktion.
\end{abstract}

\section{Schlüsselwörter}

Geoepistemologie, Andere, Macht/Raum, Regionalisierung, Spatialisierung

\section{Dušan Marinković, Dušan Ristić, Žolt Lazar}

\section{Généalogie de L'Autre et pratiques de spatialisation}

\begin{abstract}
Résumé
Le point de départ de ce travail consiste en la supposition implicite que l'existence d'un espace statique et non dialectique relevant de la géographie physique est présent dans l'anthropologie et dans la sociologie du XXème siècle. Contrairement à l'anthropologie, qui a découvert un Autre exotique et éloigné et qui, à défaut d'histoire en a fait un récit dans l'espace, la sociologie de l'Autre découvre quotidiennement son importance sociale au niveau d'une présence proche du foyer familiale. Dans ce travail nous affirmons que les Autres, découverts en premier, ont été spatialisés de manière non historique et non dialectique - comme l'espace lui-même - et que la régionalité spatiale, théorique et épistémologique, qui lui a suppléé, a conduit à une régionalisation de l'Autre. Ce travail nous mène à la conclusion selon laquelle les discours de la multitude sur les Altérités construites sur le plan régional sont apparus en anthropologie et en sciences sociales en tant que technologies sociales du pouvoir, à savoir en tant que productions de l'espace, et cela suite au tournant spatial et à la compréhension du processus de spatialisation.
\end{abstract}

\section{Mots-clés}

géo-épistémologie, Autres, pouvoir/espace, régionalisation, spatialisation 